\title{
Contents Analysis of Physical Education of Special School Curriculum in the Perspective of Transition Education for Adolescents with Disabilities
}

\author{
First HongYoung, Jang ${ }^{1}$ \\ ${ }^{1}$ Jeonju University, Dept. of Medical Sciences, Convergence Research Center for Medical Sciences, 303 \\ Chenjam-ro, Wansan-gu, Jeonju-si, 55069, Korea
}

\begin{abstract}
Background/Objectives: The purpose of this study is to analyze the trends and factors of physical educational elements, Korean career occupational curriculum and physical education, and analyze the physical education curriculums of special schools from the perspective of vertical-horizontal transition education. Methods/Statistical analysis: As for the research methodology, this study collected data by conducting a comprehensive search methodology by connecting keywords by title and theme for transition education and special school physical education curriculum research projects and literatures. For the basic education curriculum programs currently used in special schools and basic national physical education curriculums, connectivity analysis was conducted based on an analytical model founded on a perspective of vertical-horizontal transition education as proposed by Patton and Dunn. Findings: The results of analysis conducted for the basic education curriculum programs currently used in special schools and basic national physical education curriculums through such a procedure showed that in terms of the characteristic of basic education curriculum programs in special schools, vertical-horizontal transition education perspective were shown in the connectivity of fundamental conversion, by domain, by grade, and until after primary school years. As for goals, in overall goals (aims), possibilities for continued participation through systematic structuralization of physical activities; in sub-level goals, emphasize and connect all stages of physical activities to include vertical conversion perspectives. Yet such did not display contents pertaining to horizontal perspectives of transition education. As for contents, by dividing contents of physical education curriculum in stages, elements of a vertical-horizontal transition education perspective were shown to be included in terms of connectivity by level, grade, and domain which would allow a devotion to contents of physical education curriculum post primary school years as forms of leisure were shown to be included
\end{abstract}

Index Terms Contents Analysis, Physical Education, Special School Curriculum, Transition Education, Adolescents with Disabilities

\footnotetext{
Corresponding author : F. HongYoung, Jang

brighthong0@jj.ac.kr

- Manuscript received July 5, 2020.

- Revised August 10, 2020 ; Accepted September 2, 2020.

- Date of publication September 30, 2020.
}

(C) The Academic Society of Convergence Science Inc.

2619-8363 $\odot 2020$ IJBSA. Personal use is permitted, but republication/redistribution requires IJBSA permission. 


\section{INTRODUCTION}

In our society, self-reliance is the most important issue among many problems minorities have. Like others, the students who need special education also receive education through distinct phases from childhood to adulthood. Such process of changes is referred as to transition and for disabled youth, transition education is important to lead an independent life in society in the future[1]. According to recent research, vocational and career education is viewed as the essence of transition education and it is deemed to be interchangeable with transition education. This means that in Korea the concept of transition education has yet to be specifically defined in an academic way or that the education for disabled youth focuses on results, emphasizing practical aspects and pursuing more tangible educational achievements[2-4].

Physical activities also have an important influence on rehabilitation and self-reliance. The disabled adolescents who do not do enough physical activities have physical weakness and a lack of opportunities for them to exercise causes emotional, affective and social problems along with physical ones. Due to negative self-concept and a lack of selfconfidence, furthermore, three out of four disabled people suffer from chronic disorders $[5,6]$.

Likewise, to maintain physical activities for a healthy life in adulthood, it is important to develop physical activities during childhood. Since the level of physical activities during adolescence is the index to predict physical activities during adulthood, the experience to do physical activities in school has an impact on participation in leisure sports during adulthood[7,8].

Despite the importance of transition education and physical activities, nonetheless, there is little research on physical activities from the perspective of transition education for disabled youth and on the ways to promote their physical activities through policies. Therefore, this research aims to analyze national physical education, which influences adulthood, from the perspective of horizontal and vertical transition education.

\section{MeThod}

\section{A. Literature Research}

This research searched literature by typing the words such as transition education, transition education for disabled youth, curriculum of special schools and adapted physical activities for disabled youth at DBpia(http://www.dbpia.co.kr), KISS(htt p://kiss.Hstudy.com) and riss $4 \mathrm{u}(\mathrm{http}: / /$ www.riss $4 \mathrm{u}$. net).

\section{B. Analysis Process}

The following is the analysis process to fulfil the aim of this research.

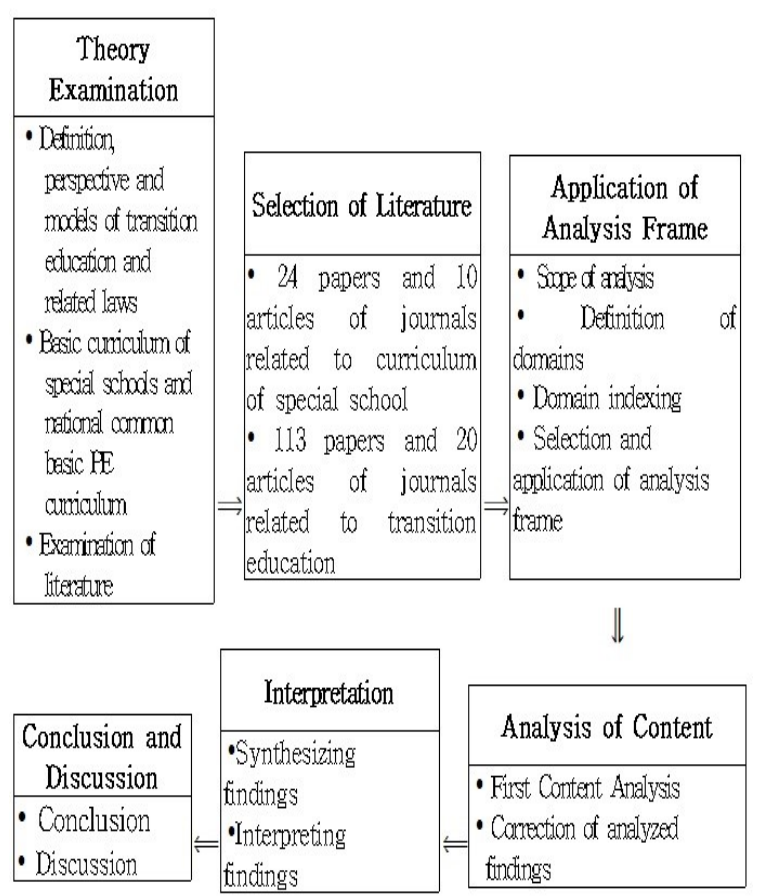

Fig. 1. Process of Literature Analysis

\begin{tabular}{|c|c|c|}
\hline \multicolumn{3}{|c|}{$\begin{array}{l}\text { Education for disabled youth } \\
\text { (Students in special schools) }\end{array}$} \\
\hline Middle School & & Intellectual, emotional, behariou, visual, hearing, \\
\hline High School & & physical disabilities \\
\hline 【I & & $\Downarrow$ \\
\hline $\begin{array}{l}\text { Transition education } \\
\text { of the US }\end{array}$ & & $\begin{array}{c}\text { Vocation and career education of } \\
\text { Korea }\end{array}$ \\
\hline Detinition/Models & & Elements of Transition Education \\
\hline $\begin{array}{c}\text { Elements of PE } \\
\text { (Leisure, Physical } \\
\text { strength) }\end{array}$ & $\Leftrightarrow$ & $\begin{array}{l}\text { Elements of PE from perspective of } \\
\text { vocation and career education } \\
\text { (Leisure, Physical strength) }\end{array}$ \\
\hline
\end{tabular}

\begin{tabular}{|c|c|c|c|}
\hline \multicolumn{4}{|c|}{$\begin{array}{l}\text { Connectivity between transition education and PE } \\
\text { curriculum of special schools }\end{array}$} \\
\hline \multicolumn{2}{|c|}{ Basic PE curriculum } & \multicolumn{2}{|c|}{$\begin{array}{l}\text { National common basic PE } \\
\text { curriculum }\end{array}$} \\
\hline \multicolumn{2}{|c|}{$\begin{array}{l}\text { From perspective of } \\
\text { transition education }\end{array}$} & \multicolumn{2}{|c|}{$\begin{array}{l}\text { From perspective of } \\
\text { transition education }\end{array}$} \\
\hline vertical & $\begin{array}{c}\text { horizont } \\
\text { al }\end{array}$ & vertical ${ }^{\text {he }}$ & horizonta \\
\hline \multicolumn{2}{|c|}{ chandenistics } & \multicolumn{2}{|c|}{\begin{tabular}{l|l} 
dranctenistics &
\end{tabular}} \\
\hline \multicolumn{2}{|c|}{ goals } & \multicolumn{2}{|l|}{ gods } \\
\hline \multicolumn{2}{|r|}{ content } & content & \\
\hline
\end{tabular}

Fig. 2. Model Analysis of PE Curriculum of Special Schools for Disabled Youth 


\section{Analysis Model}

This paper classified current basic curriculums for students with intellectual, emotional and behavior disorders and national common basic curriculum implemented by schools for the blind, deaf and physically challenged based on horizontal and vertical transition planning suggested by Patton and Dunn in order to analyze PE curriculums in special schools from the perspective of transition education for adolescents with disabilities[9].

Also, it analyzed characteristics, goals and connection with content of basic PE education and national common basic PE curriculums. <Figure $2>$ shows the two perspectives of core concepts of horizontal and vertical transition education.

$<$ Table 1> shows the analysis frame from the perspective of horizontal and vertical transition education.

Table 1. Analysis Frame from Perspective of Horizontal and Vertical Transition Education

\begin{tabular}{c|c}
\hline \hline \multicolumn{2}{c}{ Perspective of Transition Education } \\
\hline Vertical & Horizontal \\
\hline & Separated Education-Integrated \\
Domain Connectivity & Education \\
Grade Connectivity & Placement based on domicile- \\
Connectivity after School Age & community \\
& special schools -common \\
& schools \\
\hline \hline
\end{tabular}

\section{RESUlTS}

\section{A. Basic PE Curriculum from Perspective of Horizontal and Vertical Transition Education}

According to the results of analyzing the basic PE curriculum of special schools from the perspective of vertical transition education, its content is classified into three levels and consists of domains such as gymnastics, track and field, play, game and sports, expression activities and dance, physical exercise, healthcare and safety.

As a result, the content of PE does not only influence school and family life but also the lifestyle after school ages. Physical activities in school influence family life and the lifestyle after school ages and to allow to build relationship with others and to have leisure. The PE curriculum include elements of vertical transition education through a structure connecting each level, grade and domain of the content. In addition, the content of PE is centered on values of physical activities, which means that it includes the content of integrated education from the perspective of horizontal transition education.

\section{B. National Common Basic PE Curriculum from Perspective of Horizontal and Vertical Transition Education}

According to the analysis of the content of national common basic PE curriculum from the perspective of vertical transition education, they limit domains of the curriculum to five (healthcare, challenge, competition, expression and leisure activities) to moderate the amount of learning. This helps to learn the functions of exercises in depth and promotes rounded and holistic physical education by harmonizing the scientific, humanistic and artistic elements of physical activities.

This is reflected on connection to in-depth learning in national common basic curriculum of special schools and overall aspects of vertical transition education and according to the findings of analysis of the aspects of horizontal transition education of national common basic PE curriculum of special schools, PE content "officially selects affective content and provides theories at each grade," which means that it integrates cognitive, psychomotor and affective domains. That is, it contains the content of integrated education from the perspective of horizontal transition education.

\section{Connectivity between Transition Education and PE Curriculum of Special Schools}

Transition education is the education activity connected with PE curriculums of special schools. Current PE curriculums of special schools are materialized as the IEP through national, local, school levels. While the current PE curriculum is an overall education plan, the IEP is a detailed education plan whose core is to set goals tailored to the educational needs of disabled students, to choose the content to attain the set goals, to categorize the chosen content, to suggest specific strategies to be employed in teaching-learning situation at class, and to formulate a plan to provide necessary support and services.

On the other hand, transition education is to set transition domains (education, occupation, community living, independent living etc.) and consists of a series of processes such as assessment, planning, training, placement and follow-up instruction). The core is the ITP. The ITP is a comprehensive action plan that starts with assessing students' transition needs and ends with practice and action to achieve their goals. As some ancillary elements play a role to connect "teaching knowledge and skills" and "support and services" through a curriculum, the curriculum and transition education should be linked. More specifically, the IEP and the ITP should be connected. Also, it is essential to 
design a "comprehensive support plan" for a certain disabled student containing the ITP in the IEP, to link education activities such as goal, content, methods and evaluation (more specifically teachinglearning situation) with a series of supports of assessment, planning, training, placement, and a follow-up instruction to attain goals required by the ITP while implementing the IEP.

Consequently, given the current situation, it is better to connect the IEP and the ITP in all domains in elementary school, which demand less transition education in the vocation or employment domain, In middle and high schools, it is required to include transition education in the PE curriculum in any form by using classes allocated for vocation or the similar education in basic curriculum, national common basic curriculum, and selective curriculum.

\section{Conclusion \& Discussion}

This research aims at analyzing national-level PE curriculum which affects post-graduation period and is the foundation of $\mathrm{PE}$ from the perspective of horizontal and vertical transition education. The followings are findings of this research and proposals.

First, there is little content of horizontal transition education as for connection with local community, leisure and sports activities in PE curriculums of special schools. To connect transition education and PE curriculums of special schools, developing the ITP or connection between the IEP and ITP or the ITP should be done by restructuring current special school curriculums. Furthermore, it is necessary to plan a series of procedural adoption and to reflect needs of adolescents with disabilities and their parents, allowing them to receive individualized and efficient education services and the youth and their family to make decisions for themselves[10].

Second, transition education should be viewed from a more comprehensive perspective to help disabled adolescents to lead an independent life as a member of society, rather than confining it to vocation or career education.

Third, curriculums of special middle and high schools should be designed in a way for disabled youth to smoothly transition into adults and to help them to have leisure as an adult, as transition education emphasizes. Furthermore, a PE curriculum should be designed in a way to connect the students to community by analyzing an ecological system necessary for community living of disabled adolescents[11].

Fourth, it is necessary to conduct further research on a legal system to connect community and teachers and to enhance an individualized education and transition education plan in following $\mathrm{PE}$ curriculums from the perspective of transition education[11].

Finally, further research on the way to change perspectives of PE teachers is required. PE teachers should see PE as a way for disabled students to expand their physical activities in local society and to continuously improve strength, workout, sport and social skills after graduation. More research on a legal support system is urgent to lay the foundation with which disabled youth participate in sports, recreation and leisure programs in community, to connect students to local physical activity facilities and to design an individualized transition plan.

\section{REFERENCES}

[1] Kim, K. S. \& Kim, N. S. (2008). Structural Models among Vocational Transition Education, Job Performance and Job Satisfaction for the Mental Retarded School Vocational Training Course Graduates. Journal of mental retardation, 10(1), 95117.

[2] Kim, H. Y. (2005). Transition Program in the United States. Journal of Special Education, 12(2), 243-264.

[3] Yoo, A. R. (2005). Reality and Direction of Vocational Education in Special Education from a Transition Education Perspective. Journal of Vocational Rehabilitation, 15(2), 117-192

[4] Lee, K. W. (2002). The Study on Direction of Leisure Education at The time of Learning the Physical Education in School. The Korean Journal of School Physical Education, 12(2), 23-32.

[5] Lee, B. J., Choi, S. G., \& Han, D. K. (2007). The Curriculum of Adapted Physical Activity in Korean Higher Education: Current Issues and A Direction for Future. Journal of Adapted Physical Activity, 15(2), 97-115

[6] Choi, S. G. (2003). The Strategies to Promote Lifetime Sports for the People with Disabilities Utilized the Community Resources in Korea Journal of Adapted Physical Activity, 11(1), 219-230.

[7] Patricia, L. S., Gray, M. C., \& Oliver, P. K, (2000). Transition Education \& Services for Adolescents With Disabilities. Allyn \& Bacon, a Perason Education Company.

[8] Sitlington, P., Neubert, D., Begun, W., Lombard, R., \& leconte, P. (1996). Assess for success. The council for Exceptional Children, 52, 25-37.

[9] Dunn, J. M. (1997). Special physical education: Adapted, individualized, developmental(7th ed.). The McGraw-Hill Companies, Inc.

[10] Lee. Y. S., Lee, Y. S., Lee, I. D., \& Kim, H. H. (2011). Clark, G. M. (2000). Transition for Youth with Disabilities in Korea: A Systemic Review. The Korean Society of Special Education, 46(3), 131161.

[11] Cho, I. S. (2002). The Evolution Stages and Practical Tasks of Transition Education. Korean Journal of Special Education, 27(2), 175-202. 